\title{
SACRIFÍCIO DE ANIMAIS EM CERIMÔNIAS RELIGIOSAS NA PAUTA DO STF: DIREITO À LIBERDADE RELIGIOSA SOBREPOSTO AO DIREITO À VIDA ANIMAL NÃO HUMANA
}

\author{
SACRIFICE OF ANIMALS IN RELIGIOUS CEREMONIES IN THE STF PAUTA: \\ THE RIGHT TO RELIGIOUS FREEDOM OVERLOOKING THE RIGHT TO NON- \\ HUMAN ANIMAL LIFE
}

\begin{abstract}
SACRIFICIO DE ANIMALES EN CEREMONIAS RELIGIOSAS EN LA TARIFA DEL STF: DERECHO A LA LIBERTAD RELIGIOSA ANULÓ EL DERECHO A LA VIDA ANIMAL NO HUMANA
\end{abstract}

\begin{abstract}
Laura Cecília Fagundes dos Santos Braz http://orcid.org/0000-0003-3968-0923 / http://lattes.cnpq.br/4655620742116009 / lauracbraz@hotmail.com Universidade Federal da Bahia, UFBA. Salvador, BA, Brasil.
\end{abstract}

\begin{abstract}
Helena MARIA FAgUndes dos SANTOS MOTA BRAZ https://orcid.org/0000-0003-2825-8233 / http://lattes.cnpq.br/9373582225272500 / helena-braz@bol.com.br Universidade Paulista, UNIP. São José do Rio Preto, SP, Brasil. Centro Universitário Maurício de Nassau, UNINASSAU. Aracaju, SE, Brasil
\end{abstract}

TAgore Trajano de ALmeida SiLVa https://orcid.org/0000-0003-0028-486X / http: / / lattes.cnpq.br/4247501480576742 / tagoretrajano@gmail.com Universidade Federal da Bahia, UFBA. Salvador, BA, Brasil.

\section{RESUMO}

0 presente artigo destaca a relação entre humanos e animais não humanos, visando a discutir, indiretamente, o secular processo de coisificação animal e, diretamente, o sacrifício de animais em cerimônias religiosas de matriz africana face à regra proibitiva de crueldade contra os animais do art. $225, \S 1^{\circ}$, VII da CF/88. Nesse sentido, analisase o recente julgamento no Supremo Tribunal Federal - STF que culminou no reconhecimento da constitucionalidade do referido sacrifício, caracterizando-se a temática como uma das questões mais complexas e relevantes para tutela dos direitos dos animais no Brasil. Pretende-se, a partir da regra constitucional citada, abordar criticamente o julgamento do Recurso Extraordinário n. 494601 e demonstrar que o seu resultado reflete o pouco amadurecimento do STF para discutir o conflito entre o direito à liberdade religiosa e o direito à vida animal, ambos fundamentais. A metodologia utilizada envolveu a técnica de pesquisa revisão bibliográfica, consulta à legislação e doutrina especializada nacionais, e análise de precedentes judiciais provenientes do STF com temática semelhante à presente.

Palavras-chave: CF/88; Direitos dos animais; Rituais religiosos; Sacrifício animal; STF. 

DO STF: DIREITO A LIBERDADE RELIGIOSA SOBREPOSTO AO DIREITO À VIDA ANIMAL NÃO HUMANA

Laura Cecília Fagundes dos Santos Braz HELENA MARIA FAGUNDES dOS SANTOS MOTA BRAZ TAGORE TRAJANO DE ALMEIDA SiLVA

\begin{abstract}
The present article highlights the relationship between humans and nonhuman animals, aiming to discuss, indirectly, the secular process of animal reification and, directly, the sacrifice of animals in religious ceremonies of African matrix in face of the prohibitive rule of cruelty to animals of art. 225, \$1, VII of CF/88. In this sense, analyzes the recent judgment in the Supreme Federal Court - STF that culminated in the recognition of the constitutionality of said sacrifice, characterizing the issue as one of the most complex and relevant issues for the protection of animal rights in Brazil. Based on the aforementioned constitutional rule, it is intended to critically address the judgment of Extraordinary Appeal no. 494601 and demonstrate that its result reflects the poor maturity of the Supreme Court to discuss the conflict between the right to religious freedom and the right to animal life, both fundamental. The methodology used involved the research technique bibliographic review, consultation to national legislation and specialized doctrine, and analysis of judicial precedents from the Supreme Court with similar theme to the present.
\end{abstract}

Keywords: CF/88; Animal rights; Religious rituals; Animal sacrifice; STF.

\title{
RESUMEN
}

El presente artículo destaca la relación entre humanos y animales no humanos, con el objetivo de discutir, indirectamente, el proceso secular de la reificación animal y, directamente, el sacrificio de animales en ceremonias religiosas de la matriz africana frente a la regla prohibitiva de la crueldad hacia los animales del art. 225, §1, VII de CF/88. En este sentido, analiza la reciente sentencia en el Tribunal Federal Supremo - STF que culminó en el reconocimiento de la constitucionalidad de dicho sacrificio, caracterizando el tema como uno de los temas más complejos y relevantes para la protección de los derechos de los animales en Brasil. Con base en la norma constitucional mencionada anteriormente, se pretende abordar críticamente la sentencia de la Apelación Extraordinaria no. 494601 y demostrar que su resultado refleja la pobre madurez de la Corte Suprema para discutir el conflicto entre el derecho a la libertad religiosa y el derecho a la vida animal, ambos fundamentales. La metodología utilizada involucró la revisión bibliográfica de la técnica de investigación, la consulta a la legislación nacional y la doctrina especializada, y el análisis de los antecedentes judiciales de la Corte Suprema con un tema similar al presente.

Palabras clave: CF/88; Derechos de los animales; Rituales religiosos; Sacrificio animal; STF.

\section{SUMÁRIO}

INTRODUÇÃO; 1 O PROCESSO DE COISIFICAÇÃO ANIMAL E A NECESSIDADE DE ASCENSÃO DE UM NOVO PARADIGMA; 2 O DIREITO À LIBERDADE DE CULTO VERSUS DIREITO DOS ANIMAIS; 3 RE N. 494601 SACRIFÍCIO ANIMAL EM RITUAIS RELIGIOSOS DE MATRIZ AFRICANA NA PAUTA DO SUPREMO TRIBUNAL FEDERAL; CONCLUSÃO; REFERÊNCIAS.

\section{INTRODUÇÃO}

A relação do homem com a natureza é assunto que figura historicamente como objeto de grandes discussões no cenário científico-filosófico e jurídico. Nesse sentido, o presente artigo destaca a relação entre os humanos e os animais não humanos, seres que na visão da teoria contratualista racionalista, defendida por Rousseau e Kant, estão excluídos da consideração moral. Visando a discutir o processo de coisificação ao qual, secularmente, são tais animais submetidos pela humanidade e, notadamente, o sacrifício de animais em cerimônias religiosas de matriz africana. 
Como parte de seus rituais, a Umbanda e o Candomblé, religiões de matriz africana, utilizam o sacrifício de animais, o que, por si só, já consiste em tema polêmico, gerando debates calorosos não só fora, mas, inclusive, dentro das próprias comunidades religiosas. Todavia, com o advento do art. 225, § $1^{\circ}$, inciso VII, Constituição Federal de 1988, a temática tornou-se mais delicada, haja vista a previsão constitucional proibitiva de práticas de crueldade contra os animais, implicando, nesse contexto, colisão com alguns outros direitos também constitucionalmente garantidos, como é o caso do direito à liberdade de culto (art. $5^{\circ}$, inciso $\mathrm{VI}$, CF).

Sabe-se, como bem define Hannah Arendt ${ }^{1}$, que os direitos humanos não são objeto de extinção. Eles, na verdade, são uma invenção humana em constante processo de construção e reconstrução, modificando-se em consonância com uma específica época, e, tendo em vista que as leis progridem consoante o pensamento e o comportamento de uma sociedade, livre e pautada na garantia da liberdade e igualdade, possível resta verificar que os "direitos animais" têm ganhado espaço entre os debates éticos, consistindo tal nomenclatura, inclusive, em prova de que a mudança está-se perfazendo na seara jurídica.

0 ordenamento jurídico brasileiro demonstra preocupação com a proteção dos animais ${ }^{2}$, tanto individual como coletivamente, o que se depreende da previsão constitucional voltada à proteção da fauna e proibição de práticas que impliquem riscos à função ecológica e à extinção de espécies. Notadamente a vedação à crueldade contra os animais, assumindo a Magna Carta de 1988 caráter de pós-humanizada.

Neste contexto, eis que surge a necessidade de discutir, dentre as várias problemáticas que envolvem crueldade contra animais, se o abate ritualístico animal em cerimônias religiosas de matriz africana constitui uma forma de expressão religiosa protegida em caráter absoluto pela Constituição Federal. Ou ato que configura submissão à crueldade de tais seres, prática vedada pela Carta Magna de 1988 e prevista como tipo penal no art. 32 da Lei n 9.605/98 (Lei de Crimes Ambientais).

Referida questão, por sua vez, fora objeto da ADI n. 70010129690 ajuizada pelo Ministério Público do Estado do Rio Grande do Sul perante o TJRS e, posteriormente, constituiuse em matéria discutida no Recurso Extraordinário n. 494601, interposto pelo Parquet junto ao

\footnotetext{
${ }_{1}^{1}$ ARENDT, Hannah. As origens do totalitarismo. Trad. Roberto Raposo. São Paulo: Companhia das letras, 1989 , p. 49.

2 No decorrer deste artigo, utilizar-se-ão os termos "animal" e "animal não humano" como sinônimos. Sabe-se que o ser humano classifica-se como animal, mas, com o fim de melhor tratar o objeto do presente artigo, reportar-se-á a ele como "homem" ou "animal humano".
} 

DO STF: DIREITO À LIBERDADE RELIGIOSA SOBREPOSTO AO DIREITO À VIDA ANIMAL NÃO HUMANA

Laura Cecília Fagundes dos Santos Braz Helena Maria FAgundes dos SANTOS MOta BRAZ TAGore TRAJANO de ALMEIDA SILVA

Supremo Tribunal Federal, que culminou no reconhecimento da constitucionalidade do sacrifício de animais em rituais de matriz africana.

Nesse sentido, fixa-se aqui o problema do presente artigo, que consiste em saber se, ante o aparente conflito de direitos fundamentais, qual dos direitos fundamentais deve prevalecer: o direito à liberdade de consciência e crença, que garante a liberdade de expressão, de realização e prática de cultos, ou o direito que os animais têm de não serem submetidos a práticas de crueldade, ou seja, seu direito à vida?

A relevância do presente tema perfaz-se, de modo especial, no recente julgamento do RE n. $494601^{3}$, no qual os ministros do STF (Supremo Tribunal Federal) tiveram o escopo de analisar se sacrifício animal em rituais religiosos de matriz africana é compatível com a Carta Magna de 1988, questão essa que demandou ainda mais polêmica que a das vaquejadas ${ }^{4}$, sendo tal polemização, de um modo especial, retratada neste artigo mediante os posicionamentos de Daniel Braga Lourenço e Samuel Vida.

Dessa forma, este estudo pauta-se no estudo do processo de coisificação ao qual é o animal submetido historicamente, perpassa a discussão sobre a ponderação entre o direito à liberdade de culto e os direitos dos animais para, enfim, analisar os reflexos do mencionado RE n. 494601 no Direito Animal e as consequências para o movimento animalista brasileiro.

No que diz respeito à metodologia aplicada, o artigo em testilha vale-se da técnica de pesquisa revisão bibliográfica, por meio da consulta à literatura especializada, legislação e

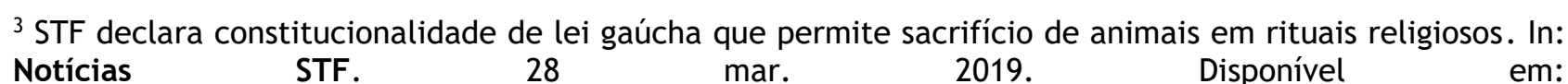
http://www.stf.jus.br/portal/cms/verNoticiaDetalhe.asp?idConteudo=407159. Acesso em: 29 ago. 2019.

${ }_{4}^{4}$ Primeiramente, conforme Gabriel Mascarenhas publicou na Folha de S. Paulo, o Supremo Tribunal Federal proibiu a realização de vaquejadas (“O STF (Supremo Tribunal Federal) proibiu nesta quinta (6) a realização de vaquejadas no Estado do Ceará. Por 6 votos a 5, os ministros puseram fim às competições em que peões montados a cavalo perseguem um boi até emparelhá-lo e derrubá-lo no chão, puxando o animal pela cauda. O plenário julgou uma ação movida pela PGR (Procuradoria-geral da República) contra a lei estadual cearense que regulamenta a vaquejada como prática desportiva e cultural. Embora trate de um caso específico, a decisão cria uma jurisprudência e abre caminho para que a festa seja proibida em outros Estado do país" (MASCARENHAS, Gabriel. STF derruba lei cearense e considera vaquejada prática ilegal. In: Folha de S. Paulo. 06 out. 2016. Disponível em: http://www1.folha.uol.com.br/cotidiano/2016/10/1820529-stf-derruba-lei-cearense-e-considera-

vaquejada-pratica-ilegal.shtml. Acesso em: 30 ago. 2019). Todavia, posteriormente, fora aprovada a Emenda Constitucional $n^{\circ} 96 / 2017$, a qual acrescentou o $\S 7^{\circ}$ ao art. 225 da Constituição Federal para determinar que práticas desportivas consideradas manifestações culturais que utilizem animais não são consideradas cruéis, sendo considerada para o movimento animalista um verdadeiro retrocesso, uma vez que se configura exceção à regra de proteção dos animais contra práticas cruéis, prevista no mesmo art. 225, § $1^{\circ}$, VII (CARVALHO FILHO, José dos Santos. Crueldade com animais: retrocesso da EC 96/2017. In: Gen Jurídico. 07 ago. 2017. Disponível em:http://genjuridico.com.br/2017/08/07/crueldade-comanimais-retrocesso-da-e-c-no-962017/. Acesso em: 10 set. 2019). 

DO STF: DIREITO À LIBERDADE RELIGIOSA SOBREPOSTO AO DIREITO À VIDA ANIMAL NÃO HUMANA

LaURa Cecília Fagundes dos Santos Braz Helena Maria FAgundes dos SANTOS MOta BRAZ TAGORE TRAJANO de ALMEIDA SILVA

documentos nacionais acerca da temática analisada. Como também conta com a análise de precedentes judiciais provenientes do Supremo Tribunal Federal - STF que, assim como o ora estudado, têm por objeto o preceito constitucional de vedação à prática de crueldade contra animais.

Por meio da revisão de literatura calcada em pesquisa doutrinária e legislativa nacional, almeja-se constatar a visão a respeito do tema apresentado e o valor de sua regulamentação. Com tais fontes, pretende-se também conhecer os diferentes posicionamentos existentes e, por meio da compilação, busca-se traçar um panorama dos pensamentos doutrinários e jurídicos da atualidade.

\section{PROCESSO DE COISIFICAÇÃO ANIMAL E A NECESSIDADE DE ASCENSÃO DE UM NOVO PARADIGMA}

As notícias sobre maus tratos a animais e limitação de sua liberdade, das quais se toma ciência diariamente, são o retrato do total desrespeito humano à natureza animal; são o reflexo da sujeição humana e coisificação animal. 0 homem, desde a sua existência, coloca-se em um patamar de superioridade quanto ao reino animal, submetendo este a uma condição de objeto. Ao assumir tal conduta, o homem nega a titularidade de direitos, como o de vida, integridade física e liberdade, aos animais não humanos que, indiscutivelmente, possuem características semelhantes às suas (a exemplo, são eles também seres sencientes ${ }^{5}$ ), aniquilando a relação de intersubjetividade entre eles.

Essa intervenção do homem na natureza é resultado da necessidade que ele tem em exercer total domínio sobre esta, determinando, para tanto, o lugar que cada coisa deve ocupar nela. Nesse sentido, Zygmunt Bauman ${ }^{6}$ ensina que, ao interferir na natureza, o homem, dentro de uma visão de pureza do mundo, não a suja. Na verdade, ele define o que é puro e o que é

\footnotetext{
${ }^{5}$ Sobre os animais serem sencientes, assim como os seres humanos, e, por isso mesmo, não sendo concebível que estejam fora da consideração moral, Peter Singer explica que "Se um ser sofre, não pode haver nenhuma justificativa de ordem moral para nos recusarmos a levar esse sofrimento em consideração. Seja qual for a natureza do ser, o princípio de igualdade exige que o sofrimento seja levado em conta em termos de igualdade com o sofrimento semelhante - até onde possamos fazer comparações aproximadas - de qualquer outro ser. Quando um ser não for capaz de sofrer, nem de sentir alegria ou felicidade, não haverá nada a ser levado em consideração. É por esse motivo que o limite de sensibilidade (para usarmos o termo com o sentido apropriado, quando não rigorosamente exato, da capacidade de sofrer ou sentir alegria ou felicidade) é o único limite defensável da preocupação com os interesses alheios [...]". (SINGER, Peter. Ética prática. Trad. Jefferson Luiz Camargo. 3. ed. São Paulo: Martins Fontes, 2002, p. 67).

6 BAUMAN, Zygmunt. 0 mal-estar da pós-modernidade. Trad. Mauro Gama, Cláudia Martinelli Gama. Revisão Técnica Luís Carlos Fridman. Rio de Janeiro: Zathar, 1998, p. 14.
} 

DO STF: DIREITO A LIBERDADE RELIGIOSA SOBREPOSTO AO DIREITO À VIDA ANIMAL NÃO HUMANA

LaURa Cecília Fagundes dos Santos Braz Helena Maria FAgundes dos SANTOS MOta BRAZ TAGORE TRAJANO de ALMEIDA SilVA

imundo, determinando, assim, as partes que compõem o mundo e que lugares devem cada uma ocupar na natureza.

Bauman $^{7}$ explica que o homem, ao buscar purificar o mundo e colocar as coisas em ordem, cria uma nova ordem, que é artificial, constituindo, assim, o que o autor chama de um "novo começo". Opera-se, com isso, uma relevante mudança no status da ordem, a qual de denomina modernidade. Na era da modernidade, então, o homem nega a ordem "tradicional”, ou seja, a ordem natural das coisas, dando início a um processo de coisificação da natureza.

Ao tratar a natureza como objeto e assumir o controle da sua própria evolução biológica, o homem assume uma postura de "protagonista da evolução". Chama-se a atenção para a necessidade de inserir as convicções morais em uma autocompreensão ética. Gabriela Rebouças $^{8}$, por sua vez, ensina que é preciso observar em que medida a teoria dos direitos fundamentais fomenta o debate jurídico e a crença num sujeito universal e absoluto, criado pela modernidade, quando na resolução de conflitos.

Analisando tais ensinamentos, percebe-se que o homem moderno, na busca por dominar a natureza, acaba até mesmo interferindo na sua própria natureza biológica, assumindo um comportamento, por vezes, amoral e antiético, que submete a natureza à condição de objeto.

E, nesse sentido, Tagore Trajano de Almeida Silva ${ }^{9}$ esclarece que é o paradigma que determina a maneira como o desenvolvimento científico a ele vinculado perfaz-se. Dessa forma, verifica-se que o paradigma da modernidade, qual seja, o da exclusão dos animais não humanos da consideração moral humana, calca-se no antropocentrismo, fundamento da teoria contratualista clássica.

À luz da referida teoria, percebe-se que os seres humanos renunciaram, lamentavelmente, à convivência harmônica com as demais formas de vida na Terra, especialmente no que diz respeito aos animais não humanos, quando deixaram de considerar-se parcela da natureza.

Precursores do contratualismo, Jean-Jacques Rousseau e Immanuel Kant, além de outros $^{10}$, defendiam a existência de um contrato social entre os animais não humanos e os

\footnotetext{
${ }^{7}$ Ibidem, pp. 19-20.

${ }^{8}$ REBOUÇAS, Gabriela Maia. Tramas entre subjetividades e direito: a constituição do sujeito em Michel Foucault e os sistemas de resolução de conflitos. Rio de Janeiro: Lumen Juris, 2012, p. 26.

9 SILVA, Tagore Trajano de Almeida. Direito animal e os paradigmas de Thomas Kuhn: reforma ou revolução científica na teoria do direito? In: Revista Brasileira de Direito Animal, v. 2, n. 3, jul/dez.2007, p. 239-269. Salvador: Instituto do Abolicionismo Animal, 2007, p. 245.

10 Têm-se como precursores desta teoria os contratualistas J. Althusius (1557-1638), T. Hobbes (15881679), B. Spinoza (1632-1677), S. Pufendorf (1632-1694), J. Locke (1632-1677), J. J. Rousseau (1712-
} 

DO STF: DIREITO À LIBERDADE RELIGIOSA SOBREPOSTO AO DIREITO À VIDA ANIMAL NÃO HUMANA

LaURa Cecília Fagundes dos Santos Braz Helena Maria FAgundes dos SANTOS MOta BRAZ TAGORE TRAJANo de ALMEIDA SILVA

homens, pelo qual apenas estes se beneficiariam ${ }^{11}$. Para Rousseau, somente o homem é um animal dotado de razão, um ser provido de luz e liberdade, com a capacidade de reconhecer seus deveres e os fundamentos da lei ${ }^{12}$.

Não obstante o fato de que "Os seres vivos classificam-se em gênero, família, ordem, classe, filo, pertencendo todas as formas de Animais ao Reino Animal ${ }^{13}$ ", tem-se, historicamente, o homem a submeter os animais não humanos à condição de suprimento de todas as suas demandas de consumo, configurando-se o que se tem por processo de coisificação dos animais.

A intervenção humana na natureza apresenta-se como fruto da necessidade que o ser humano possui de exercer total domínio sobre ela, determinando, para tanto, a função que cada elemento natural deve exercer e o lugar que nela devem ocupar.

Em meio a esse processo de coisificação da natureza e ante os ensinamentos de François Ost ${ }^{14}$, constata-se que não se pode tratar a relação entre homem e natureza de forma extremista, ou seja, sem levar em consideração as especificidades e peculiaridades de cada espécie, sob pena de negar-se, até mesmo, a sua essência e função exercida em seus habitats, sendo necessária, portanto, uma ponderação, haja vista até mesmo a intersubjetividade dos reinos vivos.

No Brasil, a temática dos direitos dos animais consiste em assunto recente. 0 reconhecimento de direitos animais no país ainda tem muito a avançar, tendo em vista que ordenamento jurídico brasileiro, até então, não abandonou suas raízes marcadamente antropocêntricas. Apesar de a Carta Magna de 1988 prever uma regra proibitória da crueldade contra os animais, acabando por reconhecê-los como seres dotados de dignidade, grande parte da doutrina não assim os concebe.

Nota-se que o legislador pátrio, ao dispor expressamente sobre a vedação à crueldade contra os animais, findou criando um dispositivo de caráter moral que, em primeiro plano, está voltado ao bem-estar animal e, de modo secundário, ao da coletividade.

1778), I. Kant (1724-1804) (BOBBIO, Norberto. [et.al]. Dicionário de Política. v. 1, 12ª . Ed, trad. João Ferreira. Brasília: Unb, 2004, p. 273).

11 BOBBIO, Norberto. [et.al]. Dicionário de Política, v. 1, 12a . ed., trad. João Ferreira. Brasília: Unb, 2004, p. 273.

12 ROUSSEAU, Jean-Jacques. Discurso sobre a origem e os fundamentos da desigualdade entre os homens. Editora Universidade de Brasília. Brasília/DF. São Paulo: Ática, 1989, p. 34-35.

${ }^{13}$ RODRIGUES, Danielle Tetü. 0 direito e os animais: uma abordagem ética, filosófica e normativa. 2 . ed. 3. reimp. Curitiba: Juruá, 2011, p. 35.

${ }^{14}$ OST, François. A natureza à margem da lei. Tradução Joana Chaves. Lisboa: Instituto Piaget, 1998, pp. 13 e 17. 

DO STF: DIREITO A LIBERDADE RELIGIOSA SOBREPOSTO AO DIREITO À VIDA ANIMAL NÃO HUMANA

LaURa CeCília FAgundes doS SANTOS BRAZ HELENA MARIA FAGUNDES dOS SANTOS MOTA BRAZ TAGORE TRAJANO DE ALMEIDA SILVA

Com isso, diz-se que, conforme leciona Laerte Fenando Levai"15, "Apesar de sua acentuada feição antropocêntrica, a Constituição da República reconhece que os animais podem sofrer, abrindo margem para a interpretação biocêntrica do preceito que veda a crueldade".

Constata-se, assim, que a Carta Magna reconhece o valor intrínseco dos animais sencientes a ponto de garantir-lhes a integridade física, operando, assim, os primeiros passos para além da perspectiva antropocêntrica clássica e, por conseguinte, adentrando no campo revolucionário do biocentrismo.

O biocentrismo, paradigma pelo qual o homem assume o dever de preservar a natureza, respeitando o valor intrínseco não só da vida humana, mas de todos os seres vivos, em especial a vida animal não humana, preconiza que os seres humanos abandonem a prática de explorar o meio ambiente para única e exclusiva satisfação dos seus próprios interesses, e passem a harmonizar-se e interagir com ele, com o escopo de proteger o bem maior: a vida em todos os seus aspectos.

Nesse contexto, mostra-se relevante observar em que medida a teoria dos direitos fundamentais incentiva o debate jurídico e a crença num sujeito universal e absoluto, criado pela modernidade, quando na resolução de $\operatorname{conflitos}^{16}$.

Dessa forma, destaca-se, à luz da teoria crítica de Thomas Kuhn, a necessidade de ascensão de um novo paradigma, pois, segundo ele, as teorias, quando não mais fornecem respostas, significam que estão a enfrentar uma crise, o que torna necessária a adoção de um novo paradigma. Segundo Kuhn, as crises significam que chegou o momento de renovar os instrumentos, ou de mudar a teoria, sendo que, no século XX, a crise da teoria defendida pelos contratualistas já era visível ${ }^{17}$, isto é, prenúncio do fim do antropocentrismo.

\section{DIREITO À LIBERDADE DE CULTO VERSUS DIREITO DOS ANIMAIS}

O estudo em testilha tem por objeto a constitucionalidade do sacrifício animal nas cerimônias religiosas ante a norma constitucional que veda a prática de crueldade contra os animais (art. 225, $\S 1^{\circ}$, VII, da $\mathrm{CF} / 88$ ) e o recente julgamento do Recurso Extraordinário $\mathrm{n}$. 494601, tendo-se por base teórica e doutrinária o entendimento de Daniel Braga Lourenço e

15 LEVAl, Laerte Fernando. Crueldade consentida: crítica à razão antropocêntrica. Revista Brasileira de Direito Animal, v. 1, n. 1, jan./dez. 2006, p. 171-190. Salvador: Instituto de Abolicionismo Animal, 2006, p. 171.

${ }^{16}$ REBOUÇAS, Gabriela Maia. Tramas entre subjetividades e direito: a constituição do sujeito em Michel Foucault e os sistemas de resolução de conflitos. Rio de Janeiro: Lumen Juris, 2012, p. 26.

$17 \mathrm{KUHN}$, Thomas S. A estrutura das revoluções científicas. trad. Beatriz Vianna Boeira e Nelson Boeira. 9a. ed. São Paulo: Perspectiva, 2003, p. 105. 

DO STF: DIREITO A LIBERDADE RELIGIOSA SOBREPOSTO AO DIREITO À VIDA ANIMAL NÃO HUMANA

LaURa Cecília Fagundes dos Santos Braz Helena Maria FAgundes dos SANTOS MOta BRAZ TAGORE TRAJANO dE ALMEIDA SILVA

Samuel Vida, como forma de demonstrar os argumentos a favor e em desfavor do sacrifício animal em cerimônias religiosas.

A tese fundamental de Daniel Braga Lourenço ${ }^{18}$ é que o núcleo essencial da liberdade religiosa das diferentes comunidades religiosas, inclusive das confissões afro-brasileiras, não restaria atingido caso, ao testar a razoabilidade e proporcionalidade, tal teste for favorável ao valor ambiental. Até no âmbito da sociologia das religiões, existe campo para a evolução. Conforme Lourenço, tanto a manipulação das forças sagradas quanto a invocação das deidades e oferendas podem efetivamente prescindir do sacrifício animal, submetendo-se sempre a novas interpretações e práticas, não se revestindo do caráter de absolutismo.

Por outro lado, os defensores do abate ritualístico em cerimônias religiosas de matriz africana, notadamente Samuel Santana Vida, sustentam, em suma, que não se tem no abate ritualístico a exploração animal, mas sim uma prática religiosa culturalmente existente. Segundo Vida $^{19}$, tal assunto fora objeto de uma ADI no Rio Grande do Sul, também analisada pelo Supremo Tribunal Federal, sendo a decisão não-unânime no Tribunal de Justiça. Referida ADI, como se verá no próximo item, fora proposta contra a Lei $n^{\circ} 12.131 / 2004$, que introduziu o parágrafo único no art. $2^{\circ}$ da Lei $n^{\circ} 11.915 / 2003$ (Rio Grande do Sul), o qual qualificou como lícito o sacrifício animal em cultos e liturgias das religiões de matriz africana.

No sistema estadunidense, utiliza-se o trabalho de David Nathan Cassuto, que aponta terem o sacrifício de animais e rituais religiosos interligações há milhares de anos. Segundo ele, a prática continua a ser parte integrante da Santeria, uma religião afrocubana que possui inúmeros adeptos nos Estados Unidos, especialmente no Estado da Flórida ${ }^{20}$.

No modelo brasileiro, Daniel Braga Lourenço assevera que a aplicação da dicotomia crença-ação, no caso, revela que a liberdade de culto pode e deve ser limitada todas as vezes em que a prática dos atos de culto da religião professada for colidente com outros valores garantidos constitucionalmente.

Como bem conclui o referido autor:

[...]0 respeito à liberdade de crença e às manifestações culturais dela relativas não pode ser encarado como um valor absoluto e não pode servir de manto

\footnotetext{
${ }^{18}$ LOURENÇO, Daniel Braga. A liberdade de culto e o direito dos animais (parte 2). Revista Brasileira de Direito Animal, v. 2, n. 3. Salvador: Instituto do Abolicionismo Animal, 2007, p. 287.

19 VIDA, Samuel Santana. Sacrifício animal em rituais religiosos liberdade de culto versus direito animal (parte 1). Revista Brasileira de Direito Animal, v. 2, n. 2. Salvador: Instituto do Abolicionismo Animal, 2007, p. 303-304.

${ }^{20}$ CASSUTO, David Nathan. Sacrifício de animais e a primeira emenda: o caso da igreja Lukumi Babalu Aye. Revista Brasileira de Direito Animal, v. 10, n. 19, p. 15-64, mai./ago.2015. Salvador: Instituto do Abolicionismo Animal, 2015, p. 16.
} 

DO STF: DIREITO A LIBERDADE RELIGIOSA SOBREPOSTO AO DIREITO À VIDA ANIMAL NÃO HUMANA

LaURa Cecília Fagundes dos Santos Braz Helena MARIA FAgundes dos SANTOS MOta BRAZ TAGORE TRAJANO de ALMEIDA SILVA

protetor de condutas que ferem outros valores relevantes. A despeito dos argumentos técnicos, pessoalmente acredito que o aprimoramento das práticas religiosas é algo possível de ser feito e envolve até mesmo um aspecto espiritual, metafísico, de se buscar, cada vez mais, uma cultura que deixe de lado os atos de violência e instrumentalização contra seres que são, em todos os pontos relevantes, semelhantes a nós, e que sofrem e possuem interesse em continuar vivendo dignamente ${ }^{21}$.

Lourenço assevera que "As liberdades públicas não são incondicionais. Como se viu, a própria legislação agasalha a teoria da dicotomia crença-ação, subordinando as manifestações culturais aos limites do estado de direito 22 ".

O autor ensina, ainda, que "A liberdade de culto, como manifestação exterior da liberdade de crença, pode, em determinadas situações, ser limitada ${ }^{23 "}$. Dessa forma, tem-se que “O respeito à liberdade de crença e às manifestações culturais dela relativas não pode ser encarado como um valor absoluto e não pode servir de manto protetor de condutas que ferem outros valores relevantes ${ }^{24 "}$.

Araújo Castro, por sua vez, explica que a liberdade de crença consiste no direito que o indivíduo tem de filiar-se à religião que desejar ou não professar religião alguma. É, na sua visão, ilimitada. Já a liberdade de culto garante a possibilidade de exteriorizar a fé, sujeitandose, pois, às restrições legais ${ }^{25}$.

Neste ambiente de conflitos cotidianos, os Poderes Públicos são tensionados a estabelecer mediações à mantença do respeito ao direito à vida animal não humana, evitando/minimizando erros históricos na busca pelo reconhecimento dos direitos dos animais. Isso será exemplificado no debate sobre o abate ritualístico nas cerimônias das religiões de matriz africana, em que cujo julgamento coube ao Judiciário procurar elementos jurídicos para legitimar a sua decisão.

Sobre o debate proposto, aduz-se que tramitou no Tribunal de Justiça do Estado do Rio Grande do Sul ADI contra a Lei $n^{\circ} 12.131 / 2004$, que introduziu o parágrafo único no art. $2^{\circ}$ da Lei estadual $n^{\circ} 11.915 / 2003$, o qual qualificou como lícito o sacrifício ritual em cultos e liturgias das religiões de matizes africanas, despertando na comunidade jurídica a necessidade de debater sobre ser, ou não, tal prática lícita ante a vedação da prática de crueldade contra os animais.

${ }^{21}$ LOURENÇO, Daniel Braga. A liberdade de culto e o direito dos animais (parte 2). Revista Brasileira de Direito Animal, v. 2, n. 3. Salvador: Instituto do Abolicionismo Animal, 2007, p. 288.

22 Ibidem, p. 279.

23 Ibidem, p. 281

${ }^{24}$ Ibidem, p. 288.

${ }^{25}$ CASTRO, Raimundo de Araújo. Nova constituição brasileira. Rio de Janeiro: Livraria Editora Freitas Bastos, 1935, p. 375. 

DO STF: DIREITO A LIBERDADE RELIGIOSA SOBREPOSTO AO DIREITO À VIDA ANIMAL NÃO HUMANA

LaURa CeCília FAgundes doS SANTOS BRAZ HELENA MARIA FAGUNDES dOS SANTOS MOTA BRAZ TAGORE TRAJANO DE ALMEIDA SILVA

Contribuindo para a concepção de que é preciso reconhecer o valor intrínseco dos animais não humanos e, por conseguinte, o caráter de crueldade do sacrifício animal em cerimônias religiosas, combatendo-se a violação do direito à vida que tais seres possuem. Destaca-se o pensamento de Joaquín Herrera Flores, o qual defende um anti-humanismo que define os direitos humanos como entidades que se localizam à margem das ações do homem, à margem do humano, direitos que devem ser considerados como dependentes de “[...] uma entidade transcendente a nossas debilidades humanas que nos protegerá, em última instância, do horror e das violações [...]", constituindo-se os direitos humanos, objetivamente, limite à ação humana ${ }^{26}$.

Segundo Lourenço ${ }^{27}$, a discussão sobre a tutela jurídica dos animais não humanos tem sido objeto de discussão acadêmica e judicial, vigorosamente, em diversos países, desde a década de 70, destacando-se os Estados Unidos da América, cujo debate tem englobado a opinião pública e conquistado a atenção e comprometimento relevante por parte de cientistas, políticos, filósofos e juristas renomados. No Brasil, a realidade não é bem essa, verificando-se que o debate que envolve a matéria pouco tem despertado interesse nos estudiosos e operadores do Direito, que, de modo habitual, preferem alocar a magnitude de assuntos em confronto, mantendo-os em segundo plano.

É bem verdade, conforme afirma Liana Oliva, que “[...] ao longo de toda a história do ordenamento jurídico brasileiro, restou presente a perseguição contra as religiões de matriz africana na positivação dos institutos jurídicos $[\ldots]^{28 ”, ~ o ~ q u e ~ s e ~ v e ̂ ~ r e f l e t i d o ~ n o ~ s e i o ~ d a ~ s o c i e d a d e ~}$ até os dias atuais, dada a visão de demonização sob a qual tais religiões são observadas.

Entretanto, o Direito Animal não pode ser visto como inimigo dos candomblicistas nem umbandistas, ou de seguidores de outras religiões que realizem o abate animal. Pois o que se está a defender, aqui, é a manutenção, preservação da vida dos animais não humanos, e não o ódio ou perseguição ao povo negro e adeptos destas religiões, quiçá se estar a negar todo o valor e importância que tem a cultura negra para o Brasil.

${ }^{26}$ FLORES, Joaquín Herrera. Os direitos humanos no contexto da globalização: três precisões conceituais. In: Revista Lugar comum, n. 25-26, 2008, p. 39-71, p. 40.

27 Daniel Braga Lourenço ministrou palestra de tema "A liberdade de culto e o direito dos animais" no Seminário "Sacrifício Animal em Rituais Religiosos: Liberdade de Culto versus Direito Animal", ocorrido no dia 06 de junho de 2007 no Auditório Raul Chaves, na Faculdade de Direito da Universidade Federal da Bahia. UFBA, Salvador/BA, organizado pelo NIPEDA. Núcleo Interdisciplinar em Direito Ambiental e Animal da UFBA.

28 OLIVA, Liana Brandão de. Direito dos animais e liberdade religiosa: uma ponderação de direitos fundamentais frente ao sacrifício animal no candomblé. 2013. 147f. Dissertação - Universidade Federal da Bahia. Salvador, 2013, p. 111. 
Essa visão deturpada e de teor persecutório acaba por levar os praticantes de tais religiões a verem os direitos animais como um instrumento jurídico voltado a mitigar o livre exercício de culto, quando, na verdade, o único escopo do movimento em prol dos direitos dos animais é ter estes efetivamente reconhecidos.

Daí a razão para a relevante repercussão gerada pelo questionamento judicial envolvendo a liberdade de culto no Rio Grande do Sul, quando a Lei n. 11.915, de 21.05.2003 (Código Estadual de Proteção aos Animais), em seu art. 16, tratou do abate de animais, prescrevendo a necessidade de utilização de métodos modernos de insensibilização prévia à sangria. O que despertou, especialmente, a atenção de setores ligados às comunidades afrobrasileiras, que, colocando pressão, conseguiram a inserção, por meio da Lei n. 12.131, de 22.07.2004, parágrafo único, ao art. $2^{\circ}$ da referida lei, segundo o qual referida vedação não alcançava o livre exercício dos cultos religiosos e liturgias das religiões de matriz africana.

Em meio às diferentes ideias sobre uso de animais em cerimônias religiosas, constata-se que, no âmbito do abate não-ritualístico (abate para alimentação), há uma evidente exploração do animal como instrumento, denotando-se daí que há coincidências entre as práticas rituais e não-rituais.

A propósito, Tom Regan ensina que inexiste exploração animal que não implique a violação dos seus interesses ou direitos básicos, pois aquela sempre implica a negação do direito que os animais têm de ser tratados com respeito, até porque não há critério de justiça que possa justificar, a um primeiro olhar, a mutilação dos seus corpos, a limitação da sua liberdade ou mesmo a sua morte ${ }^{29}$.

Os defensores do sacrifício ritual de animais não humanos em cerimônias religiosas de matriz africana (prática denominada imolação ou sacralização e considerada um símbolo milenar de suas $\operatorname{crenças}^{30}$ ) argumentam que, além de consistir em perseguição e discriminação de tais religiões. 0 discurso utilizado pelos atores do legislativo preocupados com a causa animal reside no aspecto da crueldade, só que, segundo eles, não são apenas as religiões afrorreligiosas que

${ }^{29}$ REGAN, Tom. Jaulas vazias: encarando o desafio dos direitos dos animais. Porto Alegre: Lugano, 2006, p. 126.

${ }^{30}$ ROBERT, Yannick Yves Andrade; PLASTINO, Carlos Alberto; LEITE, Fábio Carvalho. Sacrifício de animais em rituais de religiões de matriz africanas. Disponível em: http://www.pucrio.br/pibic/relatorio_resumo2008/relatorios/ccs/dir/yannick_yves_andrade_robert.pdf. Acesso em: 07 set. 2019. 

DO STF: DIREITO À LIBERDADE RELIGIOSA SOBREPOSTO AO DIREITO À VIDA ANIMAL NÃO HUMANA

LaURa Cecília Fagundes dos Santos Braz Helena Maria FAgundes dos SANTOS MOta BRAZ TAGORE TRAJANO de ALMEIDA SILVA

preparam e ofertam alimentos segundo preceitos religiosos, “[...] ao contrário, está presente histórica e atualmente em variadas confissões religiosas $[\ldots]^{31}$ ".

Todavia, ao se propor o fim do abate animal em cerimônias religiosas, pretende-se ver reconhecido o seu caráter de crueldade, logo a sua inconstitucionalidade, e não perseguir ou discriminar tais religiões, afinal sabe-se que o mundo contemporâneo é caracterizado por um multiculturalismo, logo deve prevalecer o respeito às diferenças existentes entre as mais diversas etnias e grupos sociais. Porém, é preciso ressaltar que “[...] as diferenças em si próprias não constituem valores absolutos, imunes ao exame ético, de sorte que não pode servir de manto protetor de condutas ilícitas $[\ldots]^{32}$ ".

Entende-se que a liberdade de culto, notadamente das religiões de matriz africanas, apesar de consistir em direito constitucionalmente reconhecido, não detém conteúdo valorativo absoluto, assim como qualquer outro direito por mais nobre e fundamental que seja, de modo que, a partir do momento que passa a gerar inconformismo, indignação perante outro direito, deve ser objeto de reforma ou revolução, conforme a Teoria crítica de Thomas Khun, já explicada no Capítulo 1 explicita.

Ante um conflito de direitos constitucionalmente reconhecidos, é preciso buscar a ponderação. E, em se tratando de direito à vida e direito à liberdade de culto, que, como Daniel Braga ensina, trata-se de direito não absoluto, demonstra-se que deve aquele prevalecer sobre este, ante o reconhecimento do valor da vida animal não humana.

\section{RE N. 494601 - SACRIFÍCIO ANIMAL EM RITUAIS RELIGIOSOS DE MATRIZ AFRICANA NA PAUTA DO SUPREMO TRIBUNAL FEDERAL}

A Lei $n^{\circ} 11.915$, de 21.05.2003 (Código Estadual de Proteção aos Animais), em seu art. 16, tratou do abate de animais, prescrevendo a necessidade de utilização de métodos modernos de insensibilização prévia à sangria. 0 que despertou, especialmente, a atenção de setores ligados às comunidades afro-brasileiras, que, colocando pressão, conseguiram a inserção, por meio da Lei n. 12.131, de 22.07.2004, de parágrafo único ao art. $2^{\circ}$ da Lei $n^{\circ} 11.915 / 2003$, segundo o qual referida vedação não alcançava o livre exercício dos cultos religiosos e liturgias das religiões de matriz africana, qualificando como lícito, portanto, o sacrifício ritual em cultos e liturgias das religiões de matriz africana.

31 LOURENÇO, Daniel Braga. A liberdade de culto e o direito dos animais (parte 2). Revista Brasileira de Direito Animal, vol. 2, n. 3. Salvador: Instituto do Abolicionismo Animal, 2007, p. 273.

32 Ibidem. 
O Ministério Público do Estado do Rio Grande do Sul, inconformado, interpôs recurso extraordinário, baseando-o no art.102, III, “a”, e apontando violação aos arts. 5o, caput ${ }^{33}, 19$, $\mathrm{I}^{34}$, e 22, $\mathrm{I}^{35}$, da CF, contra acórdão do Pleno do Tribunal de Justiça, cuja ementa é:

CONSTITUCIONAL. AÇÃO DIRETA. SACRIFÍCIO RITUAL DE ANIMAIS. CONSTITUCIONALIDADE.

1. Não é inconstitucional a Lei 12.131/04-RS, que introduziu parágrafo único ao art. $2^{\circ}$ da Lei 11.915/03-RS, explicitando que não infringe o "Código Estadual de Proteção aos Animais" o sacrifício ritual em cultos e liturgias das religiões de matriz africana, desde que sem excessos ou crueldade. Na verdade, não há norma que proíba a morte de animais, e, de toda sorte, no caso a liberdade de culto permitiria a prática.

2. AÇÃO JULGADA IMPROCEDENTE. VOTOS VENCIDOS.

Em análise ao caso expresso, verifica-se que o Pleno do Tribunal de Justiça do Rio Grande do Sul, ao entender que o sacrifício animal em rituais de matriz africana não fere a Lei $n^{\circ}$ 11.915/2003 (Código Estadual de Proteção aos Animais), acabou por excetuá-lo quanto à norma de proibição de práticas de crueldade contra os animais, sobrepondo o direito à liberdade de culto ao direito à vida que possuem os animais.

É possível constatar, ainda, que fora destacado no referido acórdão que não há norma que proíba a morte de animais, demonstrando, assim, uma negativa à Declaração Universal dos Direitos dos Animais $(1978)^{36}$, da qual é o Brasil signatário e em cujo art. $11^{37}$ prevê que a morte

33 “Todos são iguais perante a lei, sem distinção de qualquer natureza, garantindo-se aos brasileiros e aos estrangeiros residentes no País a inviolabilidade do direito à vida, à liberdade, à igualdade, à segurança $\mathrm{e}$ à propriedade, nos termos seguintes".

34 Art. 19. É vedado à União, aos Estados, ao Distrito Federal e aos Municípios: I - estabelecer cultos religiosos ou igrejas, subvencioná-los, embaraçar-lhes o funcionamento ou manter com eles ou seus representantes relações de dependência ou aliança, ressalvada, na forma da lei, a colaboração de interesse público.

35 Art. 22. Compete privativamente à União legislar sobre: I - direito civil, comercial, penal, processual, eleitoral, agrário, marítimo, aeronáutico, espacial e do trabalho.

${ }^{36}$ Importante destacar com relação a documentos internacionais como a referida declaração que, "Via de regra, essas declarações de direitos são conclusões ou resoluções proclamadas em conferências internacionais por instâncias desprovidas de personalidade jurídica internacional, e ainda que muitas vezes elas sejam utilizadas pelos tribunais nacionais, seus princípios e regras são imputados aos Estados participantes como simples compromissos políticos" (GORDILHO, Heron José de Santana. Abolicionismo animal. Salvador: Evolução, 2008, p. 105). Com isso, constata-se que tais declarações caracterizam-se como regras e princípios de soft law, os quais, de caráter indicativo, podem acabar por influenciar quando na criação de convenções internacionais futuras, como também na edição de regras ordinárias ou constitucionais, funcionando, inclusive, como deslegitimadoras das orientações que a elas vão de encontro (GORDILHO, Heron José de Santana. Princípios e regras de soft law: novas fontes de direito internacional ambiental. Revista Brasileira de Direito Ambiental. São Paulo, 2005, p. 129).

37 (Declaração Universal dos Direitos dos Animais). Todo o ato que implique a morte de um animal sem necessidade é um biocídio, isto é um crime contra a vida. Disponível em: http://www.crmv.am.gov.br/index.php/declaracao-dos-direitos-dos-animais/. 

DO STF: DIREITO A LIBERDADE RELIGIOSA SOBREPOSTO AO DIREITO À VIDA ANIMAL NÃO HUMANA

LaURa CECílIa FAgundes dos SANTOS BRAZ Helena Maria Fagundes dos Santos MOta BRAZ TAGore TRAJANO de ALMEIDA SILVA

desnecessária de um animal constitui-se um biocídio ${ }^{38}$.

Vê-se, portanto, que, quando se trata do uso de animais em rituais religiosos, o direito à liberdade de culto é sobreposto ao direito à vida, no caso à vida animal não humana.

Como forma de resumir todo o trâmite processual da questão acima traçada, diz-se:

Em virtude da alteração legislativa, o respectivo Procurador Geral de Justiça propôs Ação Direta de Inconstitucionalidade (Adin. $n^{\circ} 70010$ 12969) perante o Tribunal de Justiça do Rio Grande do Sul em desfavor da Assembleia Legislativa e do Governador do Estado. A ação foi julgada improcedente pelo Tribunal de Justiça do Rio Grande do Sul. O Desembargador Relator, Araken de Assis, relator do processo, entendeu que o sacrifício de animais nas cerimônias religiosas de matriz africana não configura afronta direta aos dispositivos penais estatuídos nos art. 32 da Lei Federal $n^{\circ} 9.605 / 98$ e no art. 64 da Lei de Contravenções Penais. Para ele, termos como maus-tratos e crueldade são carregados de subjetividade. Ao fazer um comparativo entre o sacrifício de animais nas liturgias e os matadouros de aves, afirmou ser impossível presumir que a morte de um animal em um culto religioso seja mais cruel do que a praticada em matadouros (RIO GRANDE DO SUL, 2005). A decisão proferida pelo Tribunal de Justiça foi objeto de Recurso Extraordinário (RE $n^{\circ}$ 494601) no Supremo Tribunal Federal, sendo distribuído em 29/09/2006 para o Ministro Marco Aurélio, e conta com parecer do Procurador-Geral da República pelo conhecimento e desprovimento do recurso ou pelo provimento parcial a fim de excluir a expressão 'matriz africana' da norma questionada, neste caso devendo permanecer com a seguinte redação: "não se enquadra nesta vedação o livre exercício dos cultos e liturgias das religiões ${ }^{39 "}$.

Em 2007, quando ainda se aguardava o julgamento do RE 494601, Daniel Braga Lourenço ${ }^{40}$ manifestou entendimento que abaixo se transcreve:

[...] Tendo embargos de declaração desacolhidos, e inconformado com a decisão de improcedência, o Ministério Público gaúcho interpôs recurso extraordinário, com fundamento no art. 102, III, alínea .a. da Constituição. Esperamos que o Supremo Tribunal Federal, ao exemplo do que fez com o leading-case envolvendo a manifestação cultural da farra-do-boi, limite, no caso concreto, a liberdade de culto no aspecto relativo ao abate ritual, vedando-o por evidente afronta ao valor ambiental constitucional, consistente no respeito ao direito à vida e na proteção dos animais contra a crueldade. A aplicação da dicotomia crença-ação, no caso, revela que a liberdade de culto pode e deve ser limitada todas as vezes em que a prática dos atos de culto da religião professada for colidente com outros valores garantidos constitucionalmente.

Nesse sentido, percebe-se que a referida ADI surgiu como um sinal de que o sacrifício de

\footnotetext{
${ }^{38}$ Ressalte-se que, em 1989, fora aprovada a Proclamação dos Direitos dos Animais, que, ao contrário da Declaração Universal dos Direitos dos Animais, tem por reivindicação a total abolição da exploração institucionalizada dos animais (DIAS, Edna Cardozo. A tutela jurídica dos animais. Belo Horizonte: Mandamentos, 2000, p. 337-340).

39 WEINGARTNER NETO, Jayme. Liberdade religiosa na Constituição: fundamentalismo, pluralismo, crenças, cultos. Porto Alegre: Livraria do Advogado, 2007, p. 288.

40 LOURENÇO, Daniel Braga. A liberdade de culto e o direito dos animais (parte 2). Revista Brasileira de Direito Animal, vol. 2, n. 3. Salvador: Instituto do Abolicionismo Animal, 2007, p. 287.
} 

DO STF: DIREITO A LIBERDADE RELIGIOSA SOBREPOSTO AO DIREITO À VIDA ANIMAL NÃO HUMANA

LaURa CeCília FAgundes doS SANTOS BRAZ HELENA MARIA FAGUNDES DOS SANTOS MOTA BRAZ TAgore Trajano de ALMEIDA SiLVA

animais em cultos religiosos é assunto que, nos tempos atuais, ainda causa muita polêmica e clamores, seja por parte dos seguidores das religiões de matriz africana. Seja por parte dos integrante do movimento animalista, seja por aqueles que as descriminam totalmente (como é o caso dos neopentecostais ${ }^{41}$ ), o que chama a atenção da comunidade jurídica como um todo para a proteção dos direitos dos animais.

Dessa forma, entende-se que, a partir do momento em que entram em conflito direitos constitucionalmente reconhecidos, deve-se ponderá-los, de modo que, quando se tem em questão o direito à vida e a liberdade de culto, deve aquele prevalecer sobre este, ante o reconhecimento dos direitos dos animais e à ética animal.

Nesse sentido, entende-se que ser necessário buscar enaltecer a supremacia do valor vida sobre o valor liberdade de culto, reavaliar o papel do Judiciário como instituição que corrobora com as mudanças sociais, bem como vislumbrar a colisão das liturgias afrorreligiosas com a proteção dos direitos dos animais, amparada pela Constituição da República Federativa do Brasil.

Desta forma, consideram-se a importância da interpretação hermenêutica e o princípio da proporcionalidade dos direitos fundamentais, a fim de perceber o direito à vida, humana e não humana, sobrepõe-se ao direito à liberdade religiosa.

É evidente a preocupação do legislador pátrio com a liberdade de crença, verificandose, porém, uma garantia reflexa da liberdade de culto, logo podendo ela ser relativizada, e, assim, não se sobrepondo à obrigação legal a todos imposta, qual seja: art. $5^{\circ}$ : VI. É inviolável a liberdade de consciência e de crença, sendo assegurado o livre exercício dos cultos religiosos e garantida, na forma da lei, a proteção aos locais de culto e suas liturgias; e VIII. Ninguém será privado de direitos por motivo de crença religiosa ou de convicção filosófica ou política, salvo para eximir-se de obrigação legal a todos imposta e recusar-se a cumprir prestação alternativa, fixada em lei.

Assim, sabe-se que, ao decidir-se pela inconstitucionalidade do sacrifício de animais em cerimônias religiosas, estar-se-á aceitando um novo paradigma: o biocêntrico, que considera

\footnotetext{
41 "O direito à liberdade religiosa é assegurado a todas as crenças, mas tem sido constantemente violado por setores evangélicos quando se trata das tradições de matriz africana. A proporção de adeptos da umbanda e do candomblé, comparada à quantidade de cristãos, é ínfima. Apesar disso, a campanha difamatória empreendida pelos neopentecostais, fomentando o ódio e incitando à violência, dá a impressão de que as religiões afro-brasileiras constituem um inimigo muito poderoso" (A identidade negra e as correntes neopentecostais são incompatíveis? Diálogos da Fé. In: Carta Capital. 04 mai. 2018. Disponível em: https://www.cartacapital.com.br/blogs/dialogos-da-fe/a-identidade-negra-e-osneopentecostais-sao-incompativeis/. Acesso em: 30 ago. 2019).
} 

DO STF: DIREITO A LIBERDADE RELIGIOSA SOBREPOSTO AO DIREITO À VIDA ANIMAL NÃO HUMANA

LaURa Cecília Fagundes dos Santos Braz Helena Maria FAgundes dos SANTOS MOta BRAZ TAGORE TRAJANO de ALMEIDA SILVA

importantes todas as formas de vida, e não só a humana, bem como reconhecendo a proteção constitucional à vida animal, isto é, a dignidade animal, explicitada na proibição de práticas cruéis contra tais seres.

Não há como negar que, ao fazer uso de animais em tais cerimônias, está o homem a instrumentalizar a vida animal não humana, logo, ao entender-se que não sejam elas alcançadas pela proibição constitucional de crueldade contra os animais, estar-se-á a dar continuidade ao combatido processo de coisificação animal, ou seja, a perpetuar a combatida teoria contratualista racionalista, vez que o que restará preponderante é a vontade humana.

Corroborando o que se aduz, tem-se Liana Brandão de Oliva, que, ao defender o abate ritualístico de animais em cerimônias do Candomblé, afirma que "[...] honrar os demais seres vivos para estas sociedades não significa, necessariamente, que animais não possam ser usados para preencher demandas e vontades humanas [... $]^{42 ”}$. Ou seja, a defesa da manutenção do sacrifício animal em tais rituais religiosos dá-se justamente (além, claro, do valor cultural e religioso que tem tal prática para os seus seguidores e para a história da cultura brasileira e do povo negro) em razão de serem os animais vistos como objetos à disposição da vontade humana, e não como seres dotados de vida e que possuem sua dignidade constitucionalmente reconhecida.

É como Heron José de Santana Gordilho expressa:

[...] a luta pelos direitos dos animais ainda enfrenta obstáculos psicológicos e conceituais muito fortes, mesmo porque ela atinge um dos mais importantes institutos do sistema jurídico: o direito de propriedade, por muitos considerado um direito natural absoluto. Por outro lado, os animais cada vez mais estão sendo reconhecidos por seu valor sentimental, pois embora tenham diferenças significativas em relação aos humanos, são dotados de sentimentos e emoções, o que nos impede de considerá-los simples coisas inanimadas ${ }^{43}$.

Porém, como já explanado nesse estudo, é possível extrair do texto constitucional um imperativo categórico em defesa dos não humanos, por meio do qual não estão os homens autorizados a ceifar, livremente, a vida de tais seres nem thes ferir a integridade ao seu belo prazer. Diz-se mais: “[...] o ser humano não é livre para interferir nas escolhas dos demais seres da Terra, esculpindo narcisicamente os moldes da vida no planeta ${ }^{44 "}$.

42 OLIVA, Liana Brandão de. Direito dos animais e liberdade religiosa: uma ponderação de direitos fundamentais frente ao sacrifício animal no candomblé. 2013. 147f. Dissertação - Universidade Federal da Bahia. Salvador, 2013, p. 17.

${ }^{43}$ GORDILHO, Heron José de Santana. Abolicionismo animal. Salvador: Evolução, 2008, p. 92.

44 SILVA, Tagore Trajano de Almeida. Direito animal \& ensino jurídico: formação e autonomia de um saber pós-humanista. Salvador: Evolução, 2014, p. 97. 

DO STF: DIREITO A LIBERDADE RELIGIOSA SOBREPOSTO AO DIREITO À VIDA ANIMAL NÃO HUMANA

LaURa CeCília Fagundes doS SANTOS BRaZ HELENA MARIA FAGUNDES dOS SANTOS MOTA BRAZ TAgore Trajano de AlmeIdA SiLVA

Corroborando o que se aduz, assevera-se que, “[...] alinhando-se ao chamado movimento do constitucionalismo "verde", o Brasil dedicou um capítulo específico para o tratamento da questão ambiental em sede constitucional [...]”, consistindo o art. 225, \$1 ${ }^{\circ}$, VII da CF/88 em uma clara determinação, dirigida ao Poder Público e à coletividade, com vistas à proteção da fauna e coibição dos atos que impliquem risco à sua função ecológica, provoquem a extinção de espécies ou submetam os animais a crueldade ${ }^{45}$.

A vedação da prática de crueldade contra os animais, segundo Lourenço e Corrêa, “[...] traduz hipótese de uma regra que descreve um comportamento proibido específico". Tem-se estabelecido, então, “[...] um comando definitivo, um dever específico (impedir práticas cruéis) e não um mandado de otimização (e.g. garantir a minimização do sofrimento animal ou o bemestar dos animais)" ${ }^{46}$.

Referidos autores esclarecem, também, que:

Ainda que possamos admitir que o conceito jurídico de "crueldade" seja indeterminado, ou aberto, quando a norma constitucional veda terminantemente a crueldade revela uma opção prévia do legislador constituinte originário em não admitir que tais atos sejam praticados. Houve, portanto, uma opção valorativa prévia adotada pela norma constitucional: atos cruéis, seja em nome de que forem praticados (e.g. religião, esporte, entretenimento, lazer, ou quaisquer outras manifestações culturais), são proibidos, são ilícitos, violam diretamente o texto constitucional ${ }^{47}$.

Não se trata, portanto, de um comando constitucional de caráter abstrato e de grau de generalidade, mas sim de regra com aplicação imediata e direta em todas as situações em que haja indícios de maus tratos em desfavor de animais. Segundo Tagore Trajano de Almeida Silva ${ }^{48}$, “[...] ]esse foi o entender do próprio constituinte ao tratar do caso de maus-tratos acontecido na farra do boi, como visto nos fundamentos do art. 225, $\$ 1^{\circ}$, VII ainda durante a Assembleia Constituinte [...]", operando-se o mesmo entendimento no caso da rinha de galo ${ }^{49}$.

\footnotetext{
45 LOURENÇO, Daniel Braga; OLIVEIRA, Fábio Corrêa Souza de. Vedação da crueldade contra animais: regra ou princípio constitucional?. In: Revista de direitos fundamentais e democracia, v. 24, n. 2, p. 222-252, mai./ago. 2019. Disponível

em: http://revistaeletronicardfd.unibrasil.com.br/index.php/rdfd/article/view/1294. Acesso em: 30 ago. 2019. p. 236.

46 Ibidem, p. 239.

47 Ibidem.

48 SILVA, Tagore Trajano de Almeida. Direito animal \& ensino jurídico: formação e autonomia de um saber pós-humanista. Salvador: Evolução, 2014, p. 97.

49 "INCONSTITUCIONALIDADE. Ação direta. Lei n 7.380/98, do Estado do Rio Grande do Norte. Atividades esportivas com aves das raças combatentes. "Rinhas" ou "Brigas de galo". Regulamentação. Inadmissibilidade. Meio Ambiente. Animais. Submissão a tratamento cruel. Ofensa ao art. 225 , § $1^{\circ}$, VII, da CF. Ação julgada procedente. Precedentes. É inconstitucional a lei estadual que autorize e regulamente, sob título de práticas ou atividades esportivas com aves de raças ditas combatentes, as chamadas "rinhas"
} 
Laura Cecília Fagundes dos Santos Braz HELENA MARIA FAgUndes dos SANTOS MOTA BRAZ Tagore Trajano de Almeida Silva

Compreende-se, com isso, que:

[...] a vedação constitucional de crueldade contra os animais deixa um claro sinal de reconhecimento da existência de um dever no tratamento e nas práticas dos seres humanos em face dos não humanos. A constitucionalização dos direitos dos animais pós-humaniza o processo interpretativo, apresentando um novo caminho, ao entender que todos (= todos os seres vivos humanos e não humanos da Terra) têm direito ao meio ambiente ecologicamente equilibrado, devendo defendê-lo e preservá-lo para as presentes e futuras gerações (= presentes e futuras gerações de vida no planeta $)^{50}$.

E, como forma de elucidar ainda mais o que se diz, colaciona-se aqui brilhante ensinamento de Andreas Krell ${ }^{51}$ :

Ao examinar a parte final do art. 225, $\S 1^{\circ}$, VII, é possível identificar que o enunciado que objetiva a vedação de práticas cruéis contra animais define um comportamento não admissível. Trata-se de uma regra que descreve imediatamente uma conduta proibida, não de um princípio que se refere a um estado de coisas a ser promovido ou atingido, "em virtude do qual deve o aplicador verificar a adequação do comportamento a ser escolhido ou já escolhido para resguardar tal estado de coisas". Na verdade, houve uma prévia ponderação do legislador constituinte, que optou por privilegiar um determinado comportamento em razão da necessidade de assegurar a efetividade do direito previsto no caput do art. 225 e de sua relevância, ante uma possível colisão com outros princípios constitucionais. Uma vez constatado que o tratamento ao qual foi submetido o animal é considerado cruel, ele necessariamente deve ser proibido ou sancionado. Ao contrário dos princípios, as regras não permitem uma ponderação com princípios ou valores constitucionais. A Constituição de 1988 podia ter estabelecido a proteção animal em forma de princípio ou "norma fim de Estado" (ex.: "O Estado promoverá o bem-estar dos animais"). Não o fez, mas escolheu a forma mais direta e protetiva, instituindo uma regra proibitiva no próprio texto do art. 225 da Constituição Federal.

Em análise ao que se expende, constata-se que a Carta Magna de 1988 caracteriza-se como pós-humanista, a partir do momento em que, através de uma interpretação hermenêutica dinâmica, vê-se por ela reconhecida a dignidade animal, o que implica dizer não ser mais concebível a exclusão dos animais não humanos da consideração moral humana.

Nesse momento, oportuno é dizer que, segundo Deckha ${ }^{52}$, "O debate sobre o status moral e jurídico dos animais aumentou nos últimos anos. No mundo jurídico a questão da

ou "brigas de galo". (STF - ADI: 3776 RN, Relator: Min. CEZAR PELUSO, Data de Julgamento: 14/06/2007, Tribunal Pleno, Data de Publicação: DJe-047 DIVULG 28-06-2007 PUBLIC 29-06-2007 DJ 29-06-2007 PP00022 EMENT VOL-02282-04 PP-00716 RTJ VOL-00202-02 PP-00620 LEXSTF v. 29, n. 343, 2007, p. 104-109 RT v. 96, n. 865, 2007, p. 118-121)". Disponível em: http: / /redir.stf.jus.br/paginadorpub/paginador.jsp?docTP=AC\&docID=469712. Acesso em: 25 ago. 2019.

50 SILVA, Tagore Trajano de Almeida. Direito animal \& ensino jurídico: formação e autonomia de um saber pós-humanista. Salvador: Evolução, 2014, p. 98.

${ }^{51}$ KRELL, Andreas Joachim; LIMA, Marcos Vinícius Cavalcante. A vedação constitucional de práticas cruéis contra animais e a correta interpretação das normas legais sobre vivissecção pelas comissões de ética no uso de animais. Revista Brasileira de Direito Animal, v. 10, n. 19, 2015, p. 113-153. p. 19. 

DO STF: DIREITO À LIBERDADE RELIGIOSA SOBREPOSTO AO DIREITO À VIDA ANIMAL NÃO HUMANA

Laura Cecílıa Fagundes dos Santos Braz Helena Maria FAgundes dos SANTOS MOta BRAZ TAGORE TRAJANO de ALMEIDA SILVA

opressão animal se tornou uma 'fronteira da justiça' [...]". Em meio a esse contexto, a referida autora chama a atenção para o fato de que "[...] negar aos animais uma "existência digna parece ser uma questão de justiça' [...]”.

Em meio a esse cenário, constata-se que a dignidade animal acaba por renovar a relação firmada entre o sistema normativo e o sistema de valores sociais, direcionando uma obrigação moral direta para com os animais não humanos; diga-se: um dever de póshumanidade, “[...] em que aqueles que o sentem não são os principais responsáveis por tal sofrimento, não sendo certo tratá-los indignamente, visto terem direitos, um crédito moral de não serem tratados de tal modo $[\ldots]^{53 "}$.

Com base no que se expõe, é que se esperava que o Supremo Tribunal Federal, ao julgar o sacrifício animal nos rituais das religiões de matriz africana, fosse pelo entendimento, assim como se operou nos casos de briga de galo ${ }^{54}$ e farra do boi $i^{55}$, de que a obrigação constitucional de garantir a todos os cidadãos o pleno exercício de direitos culturais, voltada a promover a apreciação e difusão de manifestações culturais, não o exime o Estado de observar o dispositivo constitucional que proíbe o tratamento cruel de animais ${ }^{56}$.

Entretanto, no dia 28 de março deste ano, o STF, caminhando na contramão do progresso e evolução do movimento em prol do reconhecimento dos animais, decidiu, ao julgar o Recurso Extraordinário n. 494601, por reconhecer a constitucionalidade da lei estadual gaúcha n. Lei n. 12.131, de 22.07.2004, que inseriu parágrafo único ao art. $2^{\circ}$ da Lei $\mathrm{n}^{\circ} 11.915 / 2003$ (Código Estadual de Proteção aos Animais), tornando o abate ritualístico nas religiões de matriz africana em exceção à regra insculpida naquela lei.

No julgamento do citado RE, o Vice-Procurador Geral da República, o paraibano Luciano Mariz Maia, já iniciou o seu parecer afirmando que "Somos fruto de um estupro de raças". Tão impactante quanto esta afirmação foram outras por ele feitas, tais como: "Este é um tema de

52 DECKHA, Maneesha. Ensinando ética pós-humanista na faculdade de direito: as dimensões de gênero, cultura e raça na resistência dos estudantes. Revista Brasileira de Direito Animal, v. 9, n. 15. Salvador: Instituto do Abolicionismo Animal, 2014, p. 16.

${ }^{53}$ REGAN, Tom. Jaulas vazias. Porto Alegre: Lugano, 2006, p. 47.

54 "A sujeição da vida animal a experiências de crueldade não é compatível com a Constituição do Brasil" (ADI 2.514/SC, Rel. Min. EROS GRAU - Briga de Galo - jun. 2005).

55 "A obrigação constitucional do Estado de assegurar a todos os cidadãos o pleno exercício de direitos culturais, promovendo a apreciação e difusão de manifestações culturais, não exime o Estado de observar o dispositivo constitucional que proíbe o tratamento cruel de animais". (RE/SC - Recurso Extraordinário n 153.531 - Diário da Justiça - 13 mar. 1998 - Farra do Boi).

56 "A obrigação constitucional do Estado de assegurar a todos os cidadãos o pleno exercício de direitos culturais, promovendo a apreciação e difusão de manifestações culturais, não exime o Estado de observar o dispositivo constitucional que proíbe o tratamento cruel de animais" (RE/SC - Recurso Extraordinário ${ }^{\circ}$ 153.531 - Diário da Justiça - 13/03/1998 - farra do boi). 

DO STF: DIREITO A LIBERDADE RELIGIOSA SOBREPOSTO AO DIREITO À VIDA ANIMAL NÃO HUMANA

Laura Cecília Fagundes dos Santos Braz HELENA MARIA FAgUndes dos SANTOS MOTA BRAZ Tagore Trajano de Almeida Silva

racismo, discriminação e preconceito". "Eles vinham com suas divindades, com seus deuses protetores. Aqui foram separados de suas famílias". "Eles sacrificam [esses animais] ritualmente em respeito a um direito constitucional e em respeito a um direito fundamental". "Esta, indiscutivelmente, é uma matéria institucional que revela racismo institucional". "Esse é um tema muito caro para as pessoas que são praticantes das religiões de matriz africana"57.

Mariz Maia, em meio ao seu discurso, asseverou também que:

o Brasil é o maior país africano fora da África e o segundo maior país africano, a África incluída. Nós só perdemos para a Nigéria, entretanto nós não respeitamos os valores e a cultura de matriz africana. Por isso, este Supremo Tribunal Federal, em muito boa hora, tem condição de dar sequência ao seu projeto civilizatório, sendo até contra hegemônico, para afirmar a igualdade e a dignidade de todos, e proclamar que essa lei do Rio Grande do Sul é constitucional, tem um propósito legítimo, protege e retira o estigma que sobre as religiões de matriz africana tem e, portanto, retirando um estigma, permitirá que sejam vistos iguais a todos ${ }^{58}$.

Observando-se, bem inicialmente, o discurso do citado Vice-Procurador, já era possível perceber que o julgamento do $\operatorname{RE~} n^{\circ} 494601$ não se enveredaria pelo caminho da análise e reflexão que a colisão entre o direito à vida animal não humana e à liberdade religiosa, mas sim em um momento de o Estado-Juiz, tão somente, garantir direito a uma minoria (qualitativa) que, secularmente, é vítima de perseguição, discursos de ódio e extermínio.

O que se diz acima encontra respaldo mais no voto do Relator, Ministro Marco Aurélio. Senão, veja-se:

[...] os dispositivos versam apenas o abate de animais silvestres, sem abranger os domésticos, que são utilizados nos rituais. A par desse aspecto, as regras foram fixadas em contexto alheio aos cultos religiosos, voltando-se à tutela da fauna silvestre, especialmente em atividades de caça. É impertinente arguir restrição ao exercício de direito fundamental - liberdade religiosa - sem que haja proibição legal expressa.

Admitir a prática da imolação em rituais religiosos de todas as crenças, ante o princípio da isonomia, não significa afastar a tutela dos animais estampada no artigo 225 da Constituição Federal.

[...] É necessário harmonizar a proteção da fauna com o fato de o homem ser carnívoro. Revela-se desproporcional impedir todo e qualquer sacrifício religioso de animais, aniquilando o exercício do direito à liberdade de crença de determinados grupos, quando diariamente a população consome carnes de várias

57 Trechos extraídos da gravação do julgamento do RE 494601que resta disponibilizada no Canal STF do aplicativo YouTube e transcritos por quem subscreve o presente artigo, haja vista que, até a presente data, não foram disponibilizados os votos dos Ministros no site do STF. (Pleno - Suspenso julgamento sobre sacrifício de animais em rituais religiosos (1/2). 10 ago. 2018. STF - Supremo Tribunal Federal. In: YouTube. Disponível em: https://www.youtube.com/watch?v=193qKI3Yzro. Acesso em: 01 set. 2019.)

58 Pleno - Suspenso julgamento sobre sacrifício de animais em rituais religiosos (1/2). 10 ago. 2018. STF Supremo Tribunal Federal. In: YouTube. Disponível em: https://www.youtube.com/watch?v=I93qKI3Yzro. Acesso em: 01 set. 2019). 

DO STF: DIREITO À LIBERDADE RELIGIOSA SOBREPOSTO AO DIREITO À VIDA ANIMAL NÃO HUMANA

Laura Cecília Fagundes dos SANTOS BRaz Helena MARIA FAgundes dos SANTOS MOta BRAZ TAGORE TRAJANO de ALMEIDA SILVA

espécies. Existem situações nas quais o abate surge constitucionalmente admissível, como no estado de necessidade - para a autodefesa - ou para fins de alimentação. 0 sacrifício de animais é aceitável se, afastados os maus-tratos no abate, a carne for direcionada ao consumo humano. Com isso, mantém-se o nível de proteção conferido aos animais pela Constituição Federal sem a integral supressão do exercício da liberdade religiosa ${ }^{59}$.

Na mesma linha de argumentação, tem-se o Ministro Edson Fachin:

[...] Essa dimensão comunitária da liberdade religiosa adquire, assim, nítida feição cultural e, nessa extensão, merece proteção constitucional, porquanto ligada aos modos de ser e viver de uma comunidade. Como indicou a Defensoria Pública da União em seu memorial, 'a utilização de animais é parte intrínseca à própria essência dos cultos de religiões de matriz africana, por meio do processo de sacralização'.

[...] A proteção deve ser ainda mais forte, como exige o texto constitucional, para o caso da cultura afro-brasileira, não porque seja um primus inter pares, mas porque sua estigmatização, fruto de um preconceito estrutural - como, aliás, já reconheceu esta Corte (ADC 41, Rel. Min. Roberto Barroso, Pleno, DJe 16.08.2017) -, está a merecer especial atenção do Estado.

[...] Ante, de um lado, as incertezas acerca do alcance do sofrimento animal, e, de outro, a dimensão plural que se deve reconhecer às manifestações culturais, é evidente que a proibição do sacrifício acabaria por negar a própria essência da pluralidade, impondo determinada visão de mundo a uma cultura que está a merecer, como já dito, especial Proteção constitucional ${ }^{60}$.

Ao se analisar excertos dos votos dos mencionados Ministros, constata-se a corroboração do que se verificou no parecer do Vice-Procurador Geral da República. Ou seja, enquanto se esperava que a Corte Maior fosse, efetivamente, ponderar o direito à liberdade religiosa e o direito à vida, ambos fundamentais, o que se viu, na verdade, foi um não enfrentamento da causa por ter esta, em um dos seus lados, um povo cuja existência, cultura e história segue, nos dias atuais, a ser objeto de relevante discriminação, perseguição, intolerância religiosa e, frisese, extermínio.

Esperava-se, portanto, que o Judiciário buscaria legitimar suas decisões em questões envolvendo direitos dos animais, em especial na vedação da prática cruéis atentatória à vida animal, procurando obter resultados através da ponderação entre o Direito Animal e a liberdade religiosa, com a finalidade de, no decorrer do tempo, estas decisões inéditas trazerem clareza e conteúdo para a fundamentação judicial. Contudo, com o julgamento operado em 28 de março deste ano, o que se vê é um Judiciário pouco amadurecido para apreciar tais questões,

59 Pleno - Suspenso julgamento sobre sacrifício de animais em rituais religiosos (2/2). 08 ago. 2018. STF Supremo Tribunal Federal. In: YouTube. Disponível em: https://www.youtube.com/watch?v=193qKI3Yzro . Acesso em: 01 set. 2019.

60 Ibidem. 
especialmente quando o que se tem em um dos pratos da balança é uma dívida histórica perante o povo, no caso, o povo negro brasileiro.

\section{CONCLUSÃO}

A busca do homem moderno por dominar o mundo e a si mesmo tem o levado, por muitas vezes, a desmerecer as demais espécies componentes da natureza, desenvolvendo-se um processo de coisificação desta. Em destaque, tem-se a subjetivação animal, a qual é desconsiderada quanto the é negada titularidade de direitos, tais como o direito à vida.

As notícias sobre maus tratos a animais e limitação de sua liberdade, das quais se toma ciência diariamente, são o retrato do total desrespeito humano à natureza animal; são o reflexo da sujeição humana e coisificação animal.

O homem, desde a sua existência, coloca-se em um patamar de superioridade quanto ao reino animal, submetendo este a uma condição de objeto. Ao assumir tal conduta, o homem nega a titularidade de direitos, como o direito à vida, à integridade física e à liberdade, aos animais não humanos, ao quais, indiscutivelmente, possuem características semelhantes às suas, aniquilando a relação de intersubjetividade entre eles.

Contudo, à luz do que se expõe, constata-se que a ideia de instrumentalização da natureza, defendida pelo paradigma do antropocentrismo, demonstra perder espaço no mundo como um todo, de modo que a qualidade de vida humana deixa de ser o único foco da tutela do meio ambiente, fazendo-se substituir pela proteção que também abrange os animais, dado o reconhecimento do seu valor intrínseco, residente na proteção constitucional dos seus interesses sob um viés biocêntrico.

Nesse toar, eis que surge a necessidade de questionar-se o uso de animais em rituais religiosos, não desmerecendo, em hipótese alguma, toda uma história e riqueza cultural milenar inserida pelo povo negro, mas por merecer especial atenção, e ser rechaçada, toda e qualquer prática de atividade que envolva atos de crueldade contra animais, dado o reconhecimento destes como seres sencientes, ou seja, capazes de sentir dor, sentir prazer, logo se reconhecendo como sujeitos de direitos, tais como à vida, à integridade física e à liberdade.

O STF, até antes do julgamento do RE n. 494601, parecia caminhar rumo à evolução e progresso do movimento animalista, todavia, no dia 28 de março de 2019, não se viu ser dado o passo próximo nesse processo evolutivo. 
O Poder Judiciário, agente mais importante para o movimento em prol do reconhecimento dos direitos dos animais, ao analisar e julgar colisão do direito animal com outro direito, veio e demonstrou que, caso esteja em jogo dívida perante a qual lhe falta competência, para não dizer interesse, para solvê-la, a prática proibitiva de crueldade contra os animais deve ficar em segundo plano, o que faz acender um sinal de alerta para todos aqueles que lutam pelo reconhecimento dos direitos dos animais.

Constata-se que se desprezou a crueldade a que são submetidos animais nos referidos rituais religiosos, sim, pois não se confrontou o fato de que tais seres são levados à morte sem a aplicação de métodos modernos de insensibilização, quando no Brasil matar animais não é crime, mas o é provocar-lhes a morte por simples prazer, entretenimento ou diversão, ou ainda que seja para fins de práticas religiosas, como a degola, quando se deveria reconhecer tal prática como constitucionalmente proibida.

É neste sentido que o presente artigo conclui que, ao contrário do que pensam os fiéis e seguidores das religiões de matriz africana, que festejaram o resultado do RE 494601, tal julgamento, que culminou no reconhecimento da constitucionalidade do abate de animais, seres que, como os humanos, são sencientes e, por tal razão, merecem ter o direito à vida, à integridade física e à liberdade garantidos pelo Estado e respeitados por este e por todos os agentes integrantes da sociedade brasileira, não representa respeito à cultura e à história do povo negro, mas sim, e tão-somente, um “cala-boca” a este e, concomitantemente, um sossego ao Estado, inserindo-se aí o Estado-Juiz.

Portanto, com o posicionamento a favor da liberdade religiosa para o povo negro em detrimento do direito à vida animal, o Judiciário brasileiro deixa claro ser melhor silenciar os gritos que, no passado, eram calados com a morte, do que enfrentar com vontade, compromisso e responsabilidade o problema do negro no Brasil, começando-se, por exemplo, pela adoção de práticas simples como a introdução nos livros didáticos da verdadeira história do povo afrobrasileiro, tendo por especial escopo a desmitificação do caráter demoníaco imputado às religiões de matriz africana.

Faz-se necessário e urgente, na verdade, incutir, desde o seio familiar, o respeito aos animais não humanos e o reconhecimento ao seu valor intrínseco, seu status moral, não se aceitando que o direito de liberdade de culto, que não se confunde com o direito à liberdade de crença, sobreponha-se ao direito à vida, no caso à vida animal não humana. 
SACRIFÍCIO DE ANIMAIS EM CERIMÔNIAS RELIGIOSAS NA PAUTA DO STF: DIREITO A LIBERDADE RELIGIOSA SOBREPOSTO AO DIREITO À VIDA ANIMAL NÃO HUMANA

LaURa CECÍlia FAgundes doS SANTOS BRAZ HELENA MARIA FAGUNDES dOS SANTOS MOTA BRAZ TAgore Trajano de AlmeIdA SilVA

É preciso, também, conscientizar a sociedade de que o desrespeito aos direitos dos animais é de responsabilidade de todos. E mais, o direito à vida animal não humana, como um direito fundamental, deve ser garantido pelos Poderes Públicos.

$\mathrm{E}$, assim, conclui-se que a liberdade de culto no aspecto relativo ao abate ritual deve sofrer limites por evidente afronta ao valor ambiental constitucional, qual seja: o respeito ao direito à vida e a proteção dos animais contra a crueldade.

$\mathrm{E}$, ante o que se expende no presente, conclui-se que essa negativa ao direito natural, peculiar da era moderna, deve ser combatida pelo direito positivo, através de normas que visem a uma harmoniosa relação de intersubjetividade dos reinos humano e animal. De modo que, ainda que submetendo um ao outro, garanta-lhes titularidade de direitos, contribuindo, assim, para um mundo menos antropocêntrico e, por conseguinte, mais biocêntrico.

\section{REFERÊNCIAS}

A identidade negra e as correntes neopentecostais são incompatíveis? Diálogos da Fé. In: Carta Capital. 04 mai. 2018. Disponível em: https://www.cartacapital.com.br/blogs/dialogos-dafe/a-identidade-negra-e-os-neopentecostais-sao-incompativeis/. Acesso em: 30 ago. 2019.

ARENDT, Hannah. As origens do totalitarismo. Tradução Roberto Raposo. São Paulo: Companhia das Letras, 1989.

BAUMAN, Zygmunt. 0 mal-estar da pós-modernidade. Tradução Mauro Gama, Cláudia Martinelli Gama. Revisão Técnica Luís Carlos Fridman. Rio de Janeiro: Zathar, 1998.

BOBBIO, Norberto. [et.al]. Dicionário de política, v. 1, 12ª . ed. Trad. João Ferreira. Brasília: Unb, 2004.

BRASIL. Congresso Nacional. Câmara dos Deputados. Projeto de Lei $n^{\circ} 4331 / 2012$. Acrescenta o inciso IV ao $\$ 1^{\circ}$ do Art. 29 da Lei $n^{\circ} 9.605$ de 12 de fevereiro de 1998 e dá outras providências.

Disponível em: http://www.camara.gov.br/proposicoesWeb/fichadetramitacao?

idProposicao=553718 . Acesso em: 25 ago. 2019.

BRASIL. Constituição Federal. Brasília: Senado Federal, 1988. Disponível em:

http://www.planalto.gov.br/ccivil_03/constituicao/constituicaocompilado.htm . Acesso em: 25 ago. 2019.

BRASIL. Lei $n^{\circ} 11.915$ de 21 de maio de 2003. Institui o Código Estadual de Proteção aos Animais, no âmbito do Estado do Rio Grande do Sul. In: Diário Oficial Estadual, Rio Grande do Sul, RS, 22 de maio. 2003. Disponível em:

http://lproweb.procempa.com.br/pmpa/prefpoa/seda/usu_doc/lei_estadual_11.915.pdf. Acesso em: 25 ago. 2019. 

DO STF: DIREITO A LIBERDADE RELIGIOSA SOBREPOSTO AO DIREITO À VIDA ANIMAL NÃO HUMANA

LaURa Cecília FAgundes dos Santos BraZ HELENA MARIA FAGUNDES dOS SANTOS MOTA BRAZ TAGORE TRAJANO DE ALMEIDA SILVA

BRASIL. Lei $\mathrm{n}^{\circ} 12.131$ de 22 de julho de 2004. Acrescenta parágrafo único ao artigo $2^{\circ}$ da Lei $n^{\circ}$ 11.915, de 21 de maio de 2003, que institui o Código Estadual de Proteção aos Animais, no âmbito do Estado do Rio Grande do Sul. In: Diário Oficial Estadual, Rio Grande do Sul, RS, 23 de jul. 2004. Disponível em: http://www.al.rs.gov.br/filerepository/repLegis/arquivos/12.131.pdf . Acesso em: 25 ago. 2019.

BRASIL. Supremo Tribunal Federal. Acórdão de decisão que deu provimento à ADI contra a Lei $n^{\circ} 7.380 / 98$, do Estado do Rio Grande do Norte. Ação direta $n^{\circ} 3776$ RN. Procurador-Geral da República. Relator: Ministro Cezar Peluso. 14 de junho de 2007. Disponível em: http: //redir.stf.jus.br/paginadorpub/paginador.jsp?docTP=AC\&doclD=469712. Acesso em: 25 ago. 2019.

CARVALHO FILHO, José dos Santos. Crueldade com animais: retrocesso da EC 96/2017. In: Gen Jurídico. 07 ago. 2017. Disponível em: http://genjuridico.com.br/2017/08/07/crueldade-comanimais-retrocesso-da-e-c-no-962017/. Acesso em: 10 set. 2019.

CASSUTO, David Nathan. Sacrifício de animais e a primeira emenda: o caso da igreja Lukumi Babalu Aye. Revista Brasileira de Direito Animal, v. 10, n 19, p. 15-64, mai./ago.2015, DOI: 10.9771/rbda.v10i19.14376. Salvador: Instituto do Abolicionismo Animal, 2015.

CASTRO, Raimundo de Araújo. Nova constituição brasileira. Rio de Janeiro: Livraria Editora Freitas Bastos, 1935.

DECKHA, Maneesha. Ensinando ética pós-humanista na faculdade de direito: as dimensões de gênero, cultura e raça na resistência dos estudantes. Revista Brasileira de Direito Animal, v. 9. n. 15, DOI: 10.9771/rbda.v9i15.11306. Salvador: Instituto do Abolicionismo Animal, 2014.

DIAS, Edna Cardozo. A tutela jurídica dos animais. Belo Horizonte: Mandamentos, 2000.

FLORES, Joaquín Herrera. Os direitos humanos no contexto da globalização: três precisões conceituais. In: Revista Lugar Comum, n 25-26, p. 39-71, 2008.

FLORES, Joaquín Herrera. Introdução dos direitos animais. trad. Regina Rheda. Campinas: Unicamp, 2013.

GORDILHO, Heron José de Santana. Abolicionismo animal. Salvador: Evolução, 2008.

GORDILHO, Heron José de Santana. Princípios e regras de soft law: novas fontes de direito internacional ambiental. Revista Brasileira de Direito Ambiental. ISSN 1807- 9962. São Paulo, 2005.

HABERMAS, Jürgen. 0 futuro da natureza humana: a caminho de uma eugenia liberal? trad. Karina Jannini. Revisão da tradução Eurides Avance de Souza. 2. ed. São Paulo: Martins Fontes, 2010.

KANT, Immanuel. Fundamentação da metafísica dos costumes. trad. A. Pinto de Carvalho. São Paulo: Companhia Editora Nacional, 1964. 

DO STF: DIREITO À LIBERDADE RELIGIOSA SOBREPOSTO AO DIREITO À VIDA ANIMAL NÃO HUMANA

Laura Cecília Fagundes dos Santos Braz Helena Maria Fagundes dos SANTOS MOta BRaZ TAGORE TRAJANO DE ALMEIDA SILVA

KELSEN, Hans. Teoria geral do direito e do estado. 3. ed. trad. Luis Carlos Borges. São Paulo: Martins Fontes, 1998.

KRELL, Andreas Joachim; LIMA, Marcos Vinícius Cavalcante. A vedação constitucional de práticas cruéis contra animais e a correta interpretação das normas legais sobre vivissecção pelas comissões de ética no uso de animais. Revista Brasileira de Direito Animal, v. 10, n. 19, 2015, p. 113-153.

KUHN, Thomas S. A estrutura das revoluções científicas. trad. Beatriz Vianna Doeira e Nelson Boeira. 9. ed. São Paulo: Perspectiva, 2006.

KUHN, Thomas S. A revolução copernicana: A astronomia planetária no desenvolvimento do pensamento ocidental. Lisboa: Edições 70, 1980.

KUHN, Thomas S. A estrutura das revoluções científicas. trad. Beatriz Vianna Boeira e Nelson Boeira. 9. ed. São Paulo: Perspectiva, 2003.

LEVAI, Laerte Fernando. Crueldade consentida: crítica à razão antropocêntrica. Revista Brasileira de Direito Animal, v. 1, n. 1, p. 171-190, jan./dez.2006. Salvador: Instituto de Abolicionismo Animal, 2006.

LOURENÇO, Daniel Braga. A liberdade de culto e o direito dos animais (parte 2). In: Revista Brasileira de Direito Animal, v. 2, n. 3. Salvador: Instituto do Abolicionismo Animal, 2007.

LOURENÇO, Daniel Braga; OLIVEIRA, Fábio Corrêa Souza de. Vedação da crueldade contra animais: regra ou princípio constitucional?. In: Revista de direitos fundamentais e democracia, v. 24, n. 2, p. 222-252, maio/ago. 2019. Disponível em:

http://revistaeletronicardfd.unibrasil.com.br/index.php/rdfd/article/view/1294. Acesso em: 30 ago. 2019.

OLIVA, Liana Brandão de. Direito dos animais e liberdade religiosa: uma ponderação de direitos fundamentais frente ao sacrifício animal no candomblé. 2013. 147f. Dissertação - Universidade Federal da Bahia. Salvador, 2013.

OST, François. A natureza à margem da lei. trad. Joana Chaves. Lisboa: Instituto Piaget, 1998.

Pleno - Lei gaúcha que permite sacrifício de animais em rituais religiosos é constitucional. 29 mar. 2019. STF - Supremo Tribunal Federal. In: YouTube. Disponível em:

https: //youtu.be/f2bqJHYecmQ. Acesso em: 01 set. 2019.

Pleno - Suspenso julgamento sobre sacrifício de animais em rituais religiosos (1/2). 10 ago. 2018. STF - Supremo Tribunal Federal. In: YouTube. Disponível em:

https: / /www.youtube.com/watch?v=193qKI3Yzro. Acesso em: 01 set. 2019.

Pleno - Suspenso julgamento sobre sacrifício de animais em rituais religiosos (2/2). 08 ago. 2018. STF - Supremo Tribunal Federal. In: YouTube. Disponível em:

https://www.youtube.com/watch?v=193qKI3Yzro. Acesso em: 01 set. 2019. 

DO STF: DIREITO À LIBERDADE RELIGIOSA SOBREPOSTO AO DIREITO À VIDA ANIMAL NÃO HUMANA

LaURa Cecília Fagundes dos Santos Braz Helena MARIA FAgundes dos SANTOS MOta BRAZ TAGORE TRAJANO DE ALMEIDA SILVA

REBOUÇAS, Gabriela Maia. Tramas entre subjetividades e direito: a constituição do sujeito em Michel Foucault e os sistemas de resolução de conflitos. Rio de Janeiro: Lumen Juris, 2012.

REGAN, Tom. Jaulas vazias: encarando o desafio dos direitos dos animais. Porto Alegre: Lugano, 2006.

ROBERT, Yannick Yves Andrade; PLASTINO, Carlos Alberto; LEITE, Fábio Carvalho. Sacrifício de animais em rituais de religiões de matriz africanas. Disponível em: http://www.pucrio.br/pibic/relatorio_resumo2008/relatorios/ccs/dir/yannick_yves_andrade_robert.pdf. Acesso em: 07 set. 2019.

ROUSSEAU, Jean-Jacques. Discurso sobre a origem e os fundamentos da desigualdade entre os homens. Editora Universidade de Brasília. Brasília/DF. São Paulo: Ática, 1989.

SILVA, Tagore Trajano de Almeida. Direito animal e os paradigmas de Thomas Kuhn: reforma ou revolução científica na teoria do direito? Revista Brasileira de Direito Animal, v. 2, n. 3, p. 239269, jul./dez.2007. Salvador: Instituto do Abolicionismo Animal, 2007.

SILVA, Tagore Trajano de Almeida. Direito animal \& ensino jurídico: formação e autonomia de um saber pós-humanista. Salvador: Evolução, 2014.

SINGER, Peter. Ética prática. Trad. Jefferson Luiz Camargo. 3. ed. São Paulo: Martins Fontes, 2002.

VIDA, Samuel Santana. Sacrifício animal em rituais religiosos liberdade de culto versus direito animal (parte 1). Revista Brasileira de Direito Animal, v. 2, n. 2. Salvador: Instituto do Abolicionismo Animal, 2007.

WEINGARTNER NETO, Jayme. Liberdade religiosa na Constituição: fundamentalismo, pluralismo, crenças, cultos. Porto Alegre: Livraria do Advogado, 2007.

\section{COMO FAZER REFERÊNCIA AO ARTIGO (ABNT):}

BRAZ, Laura Cecília Fagundes dos Santos; BRAZ, Helena Maria Fagundes dos Santos Mota; SILVA, Tagore Trajano de Almeida. Sacrifício de animais em cerimônias religiosas na pauta do STF: direito à liberdade religiosa sobreposto ao direito à vida animal não humana. Revista Eletrônica do Curso de Direito da UFSM, Santa Maria, RS, v. 14, n. 3, e32093, set./dez. 2019. ISSN 1981-3694. DOI: http://dx.doi.org/10.5902/1981369432093. Disponível em:

https://periodicos.ufsm.br/revistadireito/article/view/32093 Acesso em: dia mês. ano.

Direitos autorais 2019 Revista Eletrônica do Curso de Direito da UFSM

Editores responsáveis: Rafael Santos de Oliveira e Angela Araujo da Silveira Espindola 

DO STF: DIREITO À LIBERDADE RELIGIOSA SOBREPOSTO AO DIREITO À VIDA ANIMAL NÃO HUMANA

Laura CeCília FAgundes dos Santos Braz HELENA MARIA FAGUNDES DOS SANTOS MOTA BRAZ TAGORE TRAJANo de AlmEIdA Silva

Esta obra está licenciada com uma Licença Creative Commons Atribuição-NãoComercial-SemDerivações 4.0 Internacional.

\section{SOBRE OS AUTORES}

\section{LaURa Cecília Fagundes dos Santos Braz}

Laura Cecília Fagundes dos Santos Braz é Doutoranda em Jurisdição Constitucional e Novos Direitos pela Universidade Federal da Bahia-UFBA, Mestra em Direito pela Universidade Tiradentes-UNIT e Especialista em Direito Público pela UNIASSELVI. Pesquisadora do NIPEDA (Núcleo Interdisciplinar de Pesquisa e Extensão em Direitos dos Animais, Meio Ambiente e PósHumanismo). Parecerista da Revista do CEPEJ ? Centro de Estudos e Pesquisas Jurídicas/UFBA. Acadêmica da Faculdade de Letras-Português da Universidade Federal de Sergipe (UFS). Conselheira Fiscal Suplente do Instituto Abolicionista Animal IAA. Ex-Membro da Comissão de Direitos Humanos da Ordem dos Advogados do Brasil, Seccional de Sergipe (OAB/SE). ExConselheira Titular no Conselho Estadual dos Direitos da Criança e do Adolescente (representante da OAB/SE). Ex-Assessora Técnico-Jurídica da FHS (Fundação Hospitalar de Saúde/SE). Experiência em Advocacia, especialmente nas searas animalista, ambiental e cível, Assessoria e Assistência de Juiz. Ex-Subsecretária Substituta da $1^{\text {a }}$ Câmara Cível do Tribunal de Justiça do Estado de Sergipe (TJSE). Palestrante (temas jurídicos, notadamente na área de Direito Animal e Direito Ambiental). Mentora do Curso "Descomplicando o TCC". Professora de Língua Portuguesa em projetos voluntários. Coordenadora e Facilitadora de oficinas e minicursos com temas voltados ao Direito Animal. Técnica Judiciária e Conciliadora do Tribunal de Justiça do Estado de Sergipe (TJSE).

\section{HeLena MARIA FAgUndes dos SANTOS MOTA BRAZ}

Graduada em Administração de Empresas - UFS. Especialista em Análise e Gestão de Negócios - UFS. Docente na Universidade Paulista - UNIP e na Faculdade Maurício de Nassau, nos cursos de Administração de Empresas e Gestão de Recursos Humanos, lecionando Administração de Cargos e Salários, Administração estratégica, Administração Integrada, Avaliação de Desempenho, Administração Mercadológica, Comunicação e Expressão, Desenvolvimento de Recursos Humanos, Empreendedorismo, Liderança, Planejamento Estratégico, Processos Decisórios, Tecnologias da Informação, Treinamento e Desenvolvimento, Pesquisa e Extensão Empresarial. Pós-graduanda em Formação em Educação à Distância - Universidade Paulista. Mestre em Educação pelo Programa de Pós Graduação em Educação da Universidade Tiradentes. Coach de Carreira. Consultora em Gestão de Pessoas.

TAgore Trajano de ALmeida Silva

Tagore Trajano é Pós-doutor em Direito pela Pace Law School, New York/USA. Doutor e Mestre em Direito Público pela Universidade Federal da Bahia (UFBA) com estágio sanduíche como Visiting Scholar na Michigan State University (MSU/USA). Professor Efetivo Adjunto "A" da Faculdade de Direito da Universidade Federal da Bahia. Professor do Programa de Pósgraduação da Universidade Católica de Salvador (UCSal/BA). Pesquisador Visitante da University of Science and Technology of China (USTC/China). Professor Visitante da Pace Law School, Williams College e Lewis \& Clark Law School. Ex-Presidente do Instituto Abolicionista pelos Animais (www.abolicionismoanimal.org.br). Ex-Professor Pleno I do Programa de Pós-graduação em Direito da Universidade Tiradentes (Unit/SE). Professor do II Posgrado Internacional sobre "Derechos de los Animales y Sociedad Ética del Siglo XXI - Facultad de Derecho - UNNE - Corrientes - Argentina. Membro do Núcleo Interdisciplinar de Pesquisa e Extensão em Direitos dos Animais, Meio Ambiente e Pós-humanismo - NIPEDA (www.nipeda.direito.ufba.br). Coordenador Regional do Brazil-American Institute for Law and Environment - BAILE (http://www.law.pace.edu/BAILE). Editor acadêmico do site do Mestrado em Direito e Sociedade da Universidade Autônoma de Barcelona/Espanha (www.derechoanimal.info). Realiza projetos nas áreas de Direito Público, com ênfase em Direito Ambiental e Direito Animal, atuando principalmente nos seguintes temas: pós-humanismo, novas metodologias de ensino jurídico, direito comparado, bioética e sistema jurídico norte-americano. Coeditor da Revista Brasileira de Direito Animal (Salvador/BA - ISSN 1809909-2). Atualmente é Professor e Pesquisador visitante de Universidades estrangeiras, onde exerce coordenação de projetos acadêmicos. Ex-assessor da Procuradoria Cível e em projetos em Promotorias Ambientais no Ministério Público da Bahia (MPE/BA). Membro-fundador da Asociación Latinoamericana de Derecho Ambiental. Membro da Comissão de Meio Ambiente da Ordem dos Advogados do Brasil/Bahia. Advogado. 